\title{
BOVINE ABORTION ASSOCIATED WITH NEOSPORA CANINUM IN HUNGARY
}

\author{
Á. BACSADI ${ }^{*}$, E. BAJMÓCY, Katalin MATIZ and I. KISS \\ Veterinary Institute of Debrecen, H-4002 Debrecen, P.O. Box 51, Hungary
}

(Received September 13, 2000; accepted February 8, 2001)

The authors report the first case of bovine neosporosis in Hungary based on investigations made on an aborted fetus. The diagnostic methods included traditional as well as molecular techniques. This record extends further the geographic range of the disease.

Key words: Neospora caninum, bovine, neosporosis, abortions

Neosporosis is a parasitic disease with a worldwide distribution which affects both livestock and companion animals. It is caused by Neospora caninum (Apicomplexa: Sarcocystidae) which had been misdiagnosed as Toxoplasma gondii until 1988 due to the structural similarities between the two parasites.

The definitive host of the parasite is the dog (McAllister et al., 1998) but foxes were also reported as possible host and source of infection (Simpson and Monies, 1997).

In 1984, Bjerkås et al. reported the first case of encephalitis and myositis caused by the parasite in dogs. The causative agent was isolated and named by Dubey et al. in 1988. Fetal abortion due to N. caninum was first reported by Thilsted and Dubey (1989) in dairy cattle in New Mexico. Bovine neosporosis was reported as a serious cause of abortions in many countries (Dubey and Lindsay, 1996; Buxton et al., 1997; Gonzales et al., 1999). Experimental infections show that $N$. caninum can induce abortion in sheep and goats (Dubey and Lindsay, 1990; Buxton, 1998). Abortion due to N. caninum was reported in the horse too (Dubey and Porterfield, 1990).

Sréter et al. (1992) reported the first record of canine neosporosis in Hungary. Subsequently, 97 postabortion bovine sera from Hungarian herds were examined for the presence of $N$. caninum antibodies (Hornok et al., 1998). The results showed $10 \%$ positivity by ELISA. Similar examinations revealed $8 \%$ seropositivity in the UK (Otter, 1997).

This is the first report of bovine neosporosis in Hungary.

*Corresponding author; E-mail: bacsadia@indigo2.oai.hu; Fax: +36 (52) 310-823 


\section{Materials and methods}

A six-month-old aborted fetus was submitted to the Veterinary Institute of Debrecen from a dairy farm located in Eastern Hungary. The following routine and confirmatory investigations were carried out.

Bacteriology. Smears from the stomach and lungs of the fetus were stained according to Stamp's method. Culturing for the presence of bacteria and fungi was performed from the spleen, liver, lungs and stomach content of the fetus.

Histopathology. Tissue samples from the fetus were fixed in $10 \%$ buffered formalin, processed by standard methods, stained with haematoxylin and eosin (HE) and examined microscopically.

Serology. The sera of the aborted calf was examined for the presence of antibodies against Brucella, Leptospira, Chlamydia, Coxiella, Toxoplasma, Neospora, IBR and BVD virus by the respective routine serological methods.

Molecular investigations. Nucleic acid amplification from the genome of the targeted pathogen was carried out by the polymerase chain reaction (PCR) according to Ho et al. (1996). The obtained PCR products were sequenced in both directions using an ABI PRISM sequencing device. The nucleotide sequences were compared to the data stored in the GenBank.

\section{Results}

Necropsy revealed no major gross abnormality, save a moderate autolysis.

No Brucella, Chlamydia or Coxiella was detected in the smears of the stomach and lungs stained by Stamp's method.

Bacteriological and mycological cultures of the spleen, liver, lungs and stomach content of the fetus proved negative.

Microscopic lesions were seen in the brain, skeletal and heart muscles. Brain lesions were characterised as nonsuppurative granulomatous encephalitis, with focal necrosis in the grey and white matter surrounded by numerous mononuclear cells, and microglial foci of inflammation (Fig. 1). The myocardial and muscular lesions consisted of multifocal areas of myositis and infiltration with mononuclear cells, including lymphocytes and plasma cells and necrosis of myocytes (Fig. 2).

The sera of the aborted calf proved seropositive for $N$. caninum in the applied test ( $N$. caninum antibody Test Kit, IDEXX GmbH, Wörrstadt, Germany), but not against the common abortion-causing pathogens (i.e., Brucella, Leptospira, Chlamydia, Coxiella, Toxoplasma, IBR or BVD virus). 


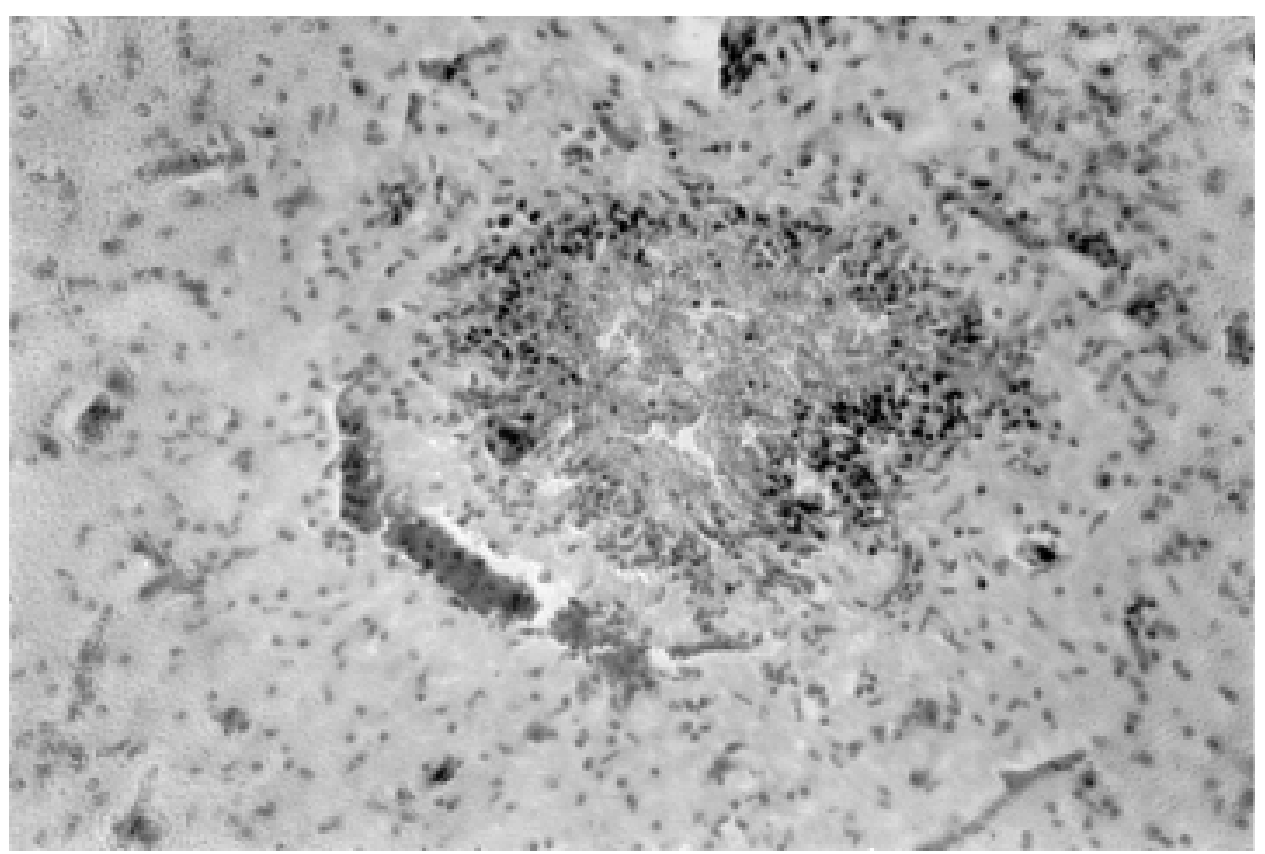

Fig. 1. Focal necrotic encephalitis. Mononuclear infiltration around the central necrotic focus. Haematoxylin-eosin (H.-E.), $\times 200$

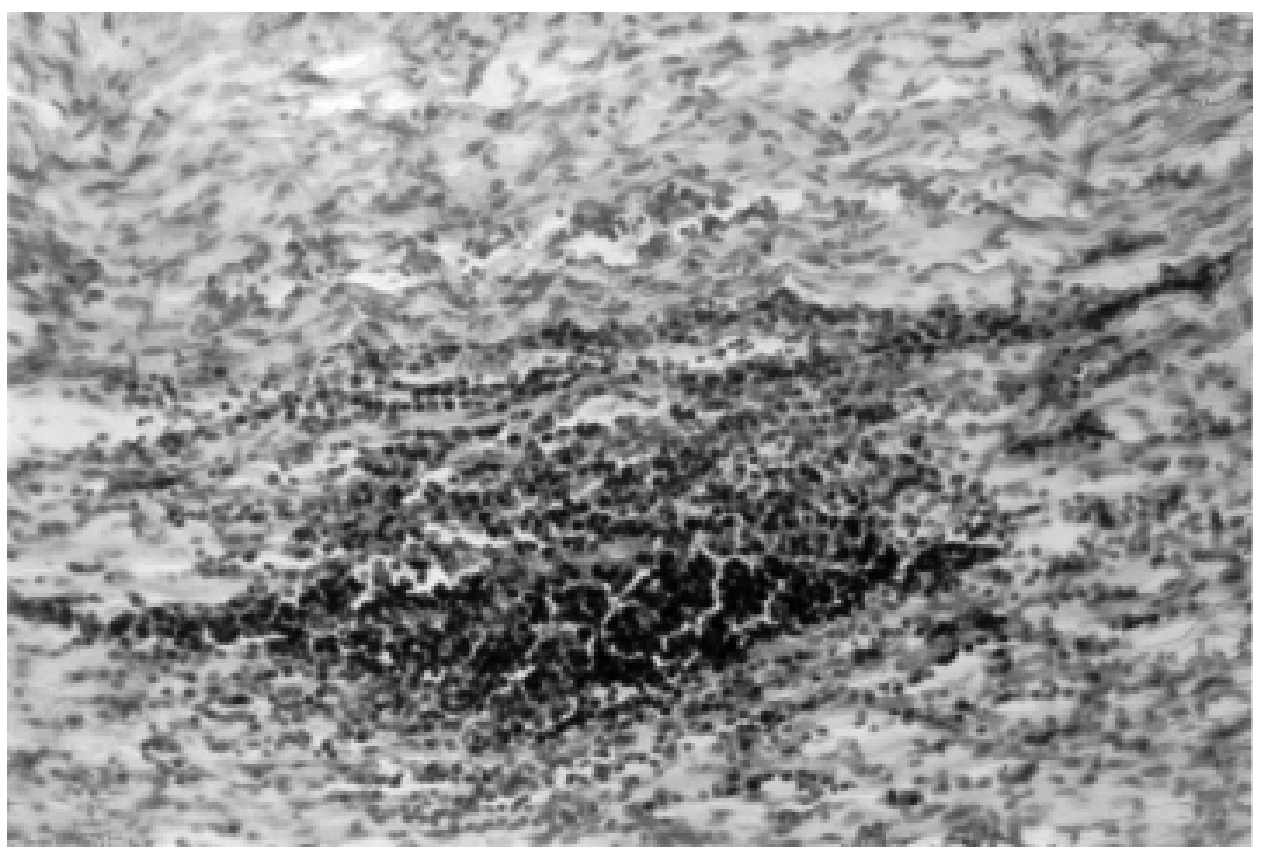

Fig. 2. Focal mononuclear myositis and necrosis of myocytes. H.-E., $\times 200$ 
Lung and brain tissue samples tested positive by PCR. The sequences of the obtained PCR products were compared to the data deposited in the GenBank and $N$. caninum was identified as their origin (Fig. 3).

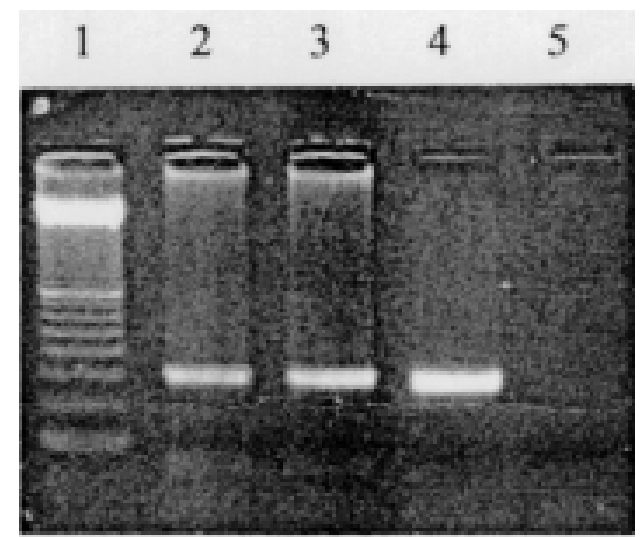

Fig. 3. Result of the Neospora caninum specific PCR assay. Lane 1: $100 \mathrm{bp}$ molecular weight marker. Lanes 2-3: Clinical samples, brain and myocardial tissue. Lane 4: Positive control. Lane 5: Negative control

\section{Discussion}

The positive identification of $N$. caninum in the aborted bovine fetus was achieved by histopathological, serological and molecular investigations. The histopathological findings were similar to those reported in other natural cases of bovine neosporosis (Dubey et al., 1990; Gonzales et al., 1999).

Based on the above findings, we report hereby the first record of bovine neosporosis in Hungary. Consequently, this record further extends the geographic range of the disease.

\section{References}

Bjerkås, I., Mohn, S. F. and Presthus, J. (1984): Unidentified cyst-forming sporozoon causing encephalomyelitis and myositis in dogs. Z. Parasitenkd. 70, 271-274.

Buxton, D. (1998): Protozoan infections (Toxoplasma gondii, Neospora caninum, Sarcocystis spp.) in sheep and goats. Vet. Res. 29, 289-310.

Buxton, D., Caldow, G. L., Maley, S. W., Marks, J. and Innes, E. A. (1997): Neosporosis and bovine abortion in Scotland. Vet. Rec. 141, 649-651.

Dubey, J. P. and Lindsay, D. S. (1990): Neospora caninum induced abortion in sheep. J. Vet. Diagn. Invest. 2, 203-233.

Dubey, J. P. and Lindsay, D. S. (1996): A review of Neospora caninum and neosporosis. Vet. Parasitol. 67, 1-59.

Dubey, J. P. and Porterfield, M. L. (1990): Neospora caninum (Apicomplexa) in an aborted equine fetus. J. Parasitol. 76, 732-734. 
Dubey, J. P., Hattel, A. L., Lindsay, D. S. and Topper, M. J. (1988): Neonatal Neospora caninum infection in dogs: Isolation of the causative agent and experimental transmission. J. Am. Vet. Med. Assoc. 193, 1259-1263.

Dubey, J. P., Miller, S., Lindsay, D. S. and Topper, M. J. (1990): Neospora caninum-associated myocarditis and encephalitis in an aborted calf. J. Vet. Diagn. Invest. 2, 66-69.

Gonzales, L., Buxton, D., Atxaerandio, R., Aduriz, E., Maley, S., Marco, J. E. and Cuerno, L. A. (1999): Bovine abortion associated with Neospora caninum in northern Spain. Vet. Rec. 144, 145-150.

Ho, M. S. Y., Barr, B. C., Marsh, A. E., Anderson, M. L., Drowe, J. D., Tarantal, A. F., Hendrickx, A. G., Sverlow, K., Dubey, J. P. and Conrad, P. A. (1996): Identification of bovine Neospora parasites by PCR amplification and specific small-subunit rRNA sequence probe hybridization. J. Clin. Microbiol. 34, 1203-1208.

Hornok, S., Näslund, K., Hajtós, I., Tanyi, J., Tekes, L., Varga, I., Uggla, A. and Björkman, C. (1998): Detection of antibodies to Neospora caninum in bovine postabortion blood samples from Hungary. Acta Vet. Hung. 46, 431-436.

McAllister, M. M., Dubey, J. P., Lindsay, D. S., Jolley, W. R., Wills, R. A. and McGuire, A. M. (1998): Dogs are definitive hosts of Neospora caninum. Int. J. Parasitol. 28, 1473-1478.

Otter, A. (1997): Neospora and bovine abortion. Vet. Rec. 140, 239.

Simpson, V. R. and Monies, R. J. (1997): Foxes and neosporosis. Vet. Rec. 141, 503.

Sréter, T., Sebestyén, P. and Dubey, J. P. (1992): Neosporosis in a dog in Hungary. Parasitol. hung. 25, 5-8.

Thilsted, J. P. and Dubey, J. P. (1989): Neosporosis-like abortions in a herd of dairy cattle. J. Vet. Diagn. Invest. 1, 205-209. 